\title{
The therapeutic potential of targeting the PI3K pathway in pediatric brain tumors
}

\author{
Hazel A. Rogers ${ }^{1}$, Jasper Estranero ${ }^{1}$, Keshni Gudka ${ }^{1}$ and Richard G. Grundy ${ }^{1}$ \\ ${ }^{1}$ Children's Brain Tumour Research Centre, School of Medicine, University of Nottingham, Nottingham, UK \\ Correspondence to: Hazel A. Rogers, email: hazel.rogers@nottingham.ac.uk \\ Keywords: PI3K pathway, brain tumor, pediatric, therapy, cancer \\ Received: September 09,2016 Accepted: November 22,2016 Published: December 02, 2016
}

\section{ABSTRACT}

Central nervous system tumors are the most common cancer type in children and the leading cause of cancer related deaths. There is therefore a need to develop novel treatments. Large scale profiling studies have begun to identify alterations that could be targeted therapeutically, including the phosphoinositide 3-kinase (PI3K) signaling pathway, which is one of the most commonly activated pathways in cancer with many inhibitors under clinical development. PI3K signaling has been shown to be aberrantly activated in many pediatric CNS neoplasms. Pre-clinical analysis supports a role for PI3K signaling in the control of tumor growth, survival and migration as well as enhancing the cytotoxic effects of current treatments. Based on this evidence agents targeting PI3K signaling have begun to be tested in clinical trials of pediatric cancer patients. Overall, targeting the PI3K pathway presents as a promising strategy for the treatment of pediatric CNS tumors. In this review we examine the genetic alterations found in the PI3K pathway in pediatric CNS tumors and the pathological role it plays, as well as summarizing the current pre-clinical and clinical data supporting the use of PI3K pathway inhibitors for the treatment of these tumors.

\section{INTRODUCTION}

Neoplasms of the CNS are the most common type of solid tumor that occur in children and the leading cause of cancer related deaths [1]. Currently prognosis for more aggressive types is relatively poor [2-4] and there is a need to identify novel therapies. Many pediatric CNS tumors have undergone extensive genomic and molecular characterization enabling identification of genetic and epigenetic alterations which could be targets for novel therapies [5-9]. One such target is the phosphoinositide 3-kinase (PI3K) pathway.

\section{PI3K PATHWAY}

The PI3K pathway is one of the most commonly activated pathways in cancer. PI3Ks are lipid kinases that activate a signaling cascade which controls diverse biological functions including cellular proliferation, survival and motility. PI3Ks can be broadly divided into three structural classes; Class I, II and III.

Class I PI3Ks can be further divided into two subtypes, Class IA and IB, dependent on their method of activation. Class IA PI3Ks are activated by receptor tyrosine kinases (RTKs), G-protein coupled receptors (GPCRs) and oncogenes, whereas Class IB PI3Ks are activated by GPRCs only [10]. Class IA PI3Ks are composed of a p 110 catalytic subunit and a p 85 regulatory subunit. There are three isoforms of the p110 catalytic subunit; $\mathrm{p} 110 \alpha, \mathrm{p} 110 \beta, \mathrm{p} 110 \delta$ and three isoforms of the p 85 regulatory subunit; $\mathrm{p} 85 \alpha, \mathrm{p} 85 \beta$, p $55 \gamma$. Class IB PI3Ks consist of a p110 $\gamma$ catalytic subunit in complex with either p101 or p87 regulatory subunits. Signaling through class I PI3Ks regulates cell growth and metabolism [11].

Class I PI3Ks activate canonical PI3K/AKT signaling. When ligands, such as growth factors or cytokines, bind to their receptor PI3K is recruited to the membrane where the regulatory subunit directly interacts with the activated receptor. After activation, class I PI3K phosphorylates the lipid phosphatidylinositol-4,5bisphosphate ( $\left.\mathrm{PIP}_{2}\right)$ to produce phosphatidylinositol-3,4,5bisphosphate ( $\mathrm{PIP}_{3}$ ). This reaction is negatively regulated by phosphate and tensin homolog (PTEN) which reduces levels of PIP 3 by converting it back to PIP $_{2}$. PIP ${ }_{3}$ forms a docking site for the recruitment of many proteins to the plasma membrane including the serine threonine kinase V-Akt murine thymoma viral oncogene homolog 
(AKT), where it is activated by phosphorylation by phosphoinositide-dependent protein kinase 1 (PDK1) and mammalian target of rapamycin complex 2 (mTORC2). Once activated, AKT regulates key cellular activities downstream, including glycogen synthesis by the forkhead family of transcription factors (FOXOs) and apoptosis through p53, BAD and NfkB (Figure 1) [11].

Alternative mechanisms of PI3K pathway activation can be mediated by small GTPases such as Ras. Ras is capable of activating Class I PI3K isoforms p110 $\alpha$, p110 and $\mathrm{p} 110 \delta$ by binding to the RAS-Binding Domain. Class I p110 $\beta$ can also be regulated by the Rho family of GTPases, particularly RAC1 and CDC42 [12].

One target of PI3K signaling that has commonly been implicated in cancer is mammalian target of rapamycin (mTOR). Signaling through mTOR regulates key cellular activities including cell growth and protein synthesis [13]. mTOR forms two complexes to exert its downstream actions, mammalian target of rapamycin complex 1 (mTORC1) and mammalian target of rapamycin complex 2 (mTORC2), which are differentially regulated by upstream signals. Both can be regulated by PI3K signaling. AKT phosphorylates tuberous sclerosis 2 (TSC2) and proline rich AKT substrate $40 \mathrm{kDa}$ (PRAS40) which attenuates their inhibitory effects on mTORC1 [14]. PI3K signaling has recently been linked to activation of $\mathrm{mTORC} 2$ where $\mathrm{PIP}_{3}$ has been identified as a direct upstream activator [15].

Class II PI3Ks consist of a single catalytic subunit of which there are three isoforms $\mathrm{PI} 3 \mathrm{KC} 2 \alpha, \mathrm{PI} 3 \mathrm{KC} 2 \beta$ and PI3KC $2 \gamma$. They can be activated by RTKs, cytokine receptors and integrins. Their specific cellular functions remain poorly understood. Recent evidence suggests signaling may play a role in angiogenesis, growth and survival [16]. Class III PI3K consists of a single catalytic subunit VPS34. Signaling through this PI3K class has been linked to roles in cellular trafficking and regulation of autophagy [17].

\section{PI3K SIGNALING AND CANCER}

Signaling through class I PI3Ks has commonly been implicated in cancer. A number of genetic alterations resulting in pathway activation have been identified. PTEN is one of the most frequently inactivated tumor suppressor genes, with loss commonly occurring through deletions and inactivating mutations [18]. Loss of PTEN results in a lack of control of $\mathrm{PIP}_{3}$ levels and un-restrained PI3K signaling.

PI3KCA, which encodes the $\mathrm{p} 110 \alpha$ catalytic subunit of class IA PI3K, is frequently mutated in some of the most common human cancers $[19,20] .80 \%$ of reported mutations cause amino acid substitutions in the helical and kinase domains and result in activation of class IA PI3K [21]. Mutations can also occur in $\mathrm{p} 110 \beta$ and $\mathrm{p} 110 \delta$ but are less common. Alternatively amplification or overexpression of these genes has been reported [22]. Mutations have also been identified in the regulatory PI3K subunits, usually in the form of substitutions or inframe deletions or insertions. This includes PI3KRI which encodes the regulatory subunit $\mathrm{p} 85 \alpha$, where mutations have been found in $10 \%$ of glioblastomas [19].

Activating mutations or amplifications of $A K T 1 / 2$ have also been identified [23]. Mutations are rarely seen in PDPK1 but amplification or overexpression has been detected in breast cancer [24]. Class I PI3K signaling activation can also result from activating mutations in $R A S$, the most highly mutated oncogene in cancer [25].

Class II PI3K isoforms are less well understood. However, they have been implicated in cancer. Amplification and somatic mutations have been identified in PIK3C2B [26]. However, the functional implications of these alterations are not understood.

Mutations have also been identified in the negative regulators of mTOR signaling TSC1 and TSC2. Mutations in these genes occur in the familial syndrome tuberous sclerosis complex (TSC), a rare autosomal dominant disorder. Patients with TSC develop benign tumors in multiple organs including brain, heart, kidney, lungs and skin [27]. Loss of TSC1/2 also occurs at low frequency in sporadic cancer $[28,29]$.

The common occurrence of PI3K pathway deregulation in cancer has sparked interest in the development of inhibitors targeting PI3K signaling, with over 30 inhibitors being trialed clinically (Figure 2). The first generation of PI3K inhibitors, wortmanin and LY294002, are broad spectrum with their clinical effectiveness limited by high toxicity and poor solubility [11]. Currently, three main classes of PI3K inhibitors are in clinical development; pan-Class I PI3K, dual panClass I PI3K/mTOR and PI3K isoform specific [30]. The first inhibitor to be approved for treatment was the PI3K $\delta$ isoform inhibitor idelalisib for treatment of B-cell malignancies [31]. However, in general only modest effects have been seen in trials of PI3K pathway inhibitors to date [30]. Inhibitors targeting AKT have also been developed. The most advanced clinically is perifosine, a lipid based phosphatidylinositol targeting the homology domain of AKT and impeding its translocation to the plasma membrane [32].

Agents targeting mTOR signaling are more clinically advanced than other nodes of the pathway. The first inhibitor to be discovered was rapamycin, a bacterially derived product which was originally developed as a fungicidal and immunosuppressive drug [11, 33]. Analogues of rapamycin with better pharmacological properties, called rapalogues, such as everolimus and temsirolimus have subsequently been developed [34]. Improved survival has been seen with rapalogues in patients with some cancers [33] and two rapalogues, temsirolimus and everolimus, are currently approved for cancer treatment [35-37]. However, modest 
outcomes have been seen in clinical trials for other tumor types [33]. Additionally, rapalogues only inhibit mTORC1. Inhibitors that target both mTORC1 and 2 have begun to be developed which induce more potent inhibition of mTORC1 and also block mTORC2 [38].

Recent evidence also suggests that PI3K inhibition can be used not only to target tumor cells directly but also the surrounding stroma, including tumor vasculature and infiltrating immune cells $[39,40]$. The clinical efficacy of idelalisib in the treatment of B cell malignancies is in part due to interference in the interaction of cancer cells with the surrounding tumor stroma [41]. Studies also suggest PI3K inhibition could be used to promote a tumor specific immune response [42].

\section{PI3K PATHWAY IN PEDIATRIC BRAIN TUMORS}

\section{Pediatric high grade glioma (pHGG)}

pHGG account for $5-10 \%$ of all pediatric CNS tumors. Prognosis for children with $\mathrm{pHGG}$ is dismal with a 5 year survival rate of less than $20 \%$ [2]. pHGG encompass a number of variants including glioblastoma, anaplastic astrocytoma, anaplastic oligodendroglioma, gliomatosis cerebri and diffuse intrinsic pontine glioma (DIPG).

Activation of PI3K signaling has been found in a high percentage of $\mathrm{pHGG}$, which in some studies was linked to a poorer prognosis $[5,43,44]$. This is similar to adult HGGs where PI3K pathway activation has also commonly been seen and found to be strongly associated with a poorer prognosis [45].

However, the mechanism of aberrant pathway activation differs between adult and pediatric tumors. In adult tumors inactivating PTEN mutations are commonly seen. In contrast, in pediatric cases they are infrequent [46]. However, inactivation of PTEN through promoter methylation has been reported [47], while allelic loss through deletions have been found in DIPG [48]. Activating mutations in PIK3CA have also been detected in pHGG. Gallia et al identified mutations in $21 \%$ of pediatric glioblastomas which was similar to rates identified in adult glioblastomas (17\%) [49]. Grill et al also identified PIK3CA mutations in 15\% of DIPGs [50].

Pathway activation through amplification or overexpression of growth factor receptors is also common. Amplification or overexpression of EGFR was commonly found in adult HGGs but was rarely seen in pHGG [8]. However, overexpression has been reported [44, 46]. EGFRvIII mutations have also been identified [51, 52]. The predominant target of amplification in $\mathrm{pHGGs}$ is PDGFRA, particularly in DIPG $[8,48,51]$. Amplifications were found in $11 \%$ of non-brainstem pHGGs and $26 \%$ of
DIPGs. Somatic point mutations in PDGFRA have also been identified in $14 \%$ of non-brainstem pHGGs and $5 \%$ of DIPGs [53]. Amplification of other members of the PI3K signaling pathway have also been reported at low frequencies [8].

A recent whole genome sequencing study identified frequent activation of PI3K signaling through mutations in $67 \%$ of non-brainstem HGGs and $69 \%$ of DIPGs, including fusions involving the kinase domain of neurotrophin receptor (NTRK) genes, highlighting the importance of this signaling pathway in these tumors [52]. However, a multiregional sequencing study of DIPG suggested PI3K signaling mutations were sub-clonal rather than driver mutations [54].

\section{Pediatric low grade glioma (pLGG)}

pLGG are the most common type of pediatric brain tumor and account for approximately $40 \%$ of cases [55]. pHGG encompass a range of variants with the most common being pilocytic astrocytoma [55]. Prognosis is relatively good, however those that cannot be surgically removed can cause morbidity and there is therefore a need to identify novel therapies $[55,56]$.

PI3K signaling has been implicated in pLGG. mTOR activation has been associated with subependymal giant cell astrocytoma (SEGA) which occurs in up to $15 \%$ of TSC patients [57]. Evidence of PI3K activity has also been found in other types of pLGG. Proteomic analysis demonstrated mTOR activation across pLGG subtypes [58, 59]. mTOR activation has also been linked to clinically aggressive and anaplastic subsets of pilocytic astrocytomas [60]. Additionally, FGFR1 duplications and $M Y B$ rearrangements have been shown to activate PI3K signaling in pLGG [56].

Pre-clinical analysis has produced evidence supporting the potential for therapeutic targeting using mTOR inhibitors in pLGG. Decreased growth was seen when two pLGG cell lines were treated with an mTORC1 inhibitor [58]. Kaul et al demonstrated a link between the BRAF fusion commonly found in pLGG and mTOR signaling, where neural stem cell proliferation driven by the BRAF fusion was shown to be mediated through mTOR signaling [61]. This was supported by the significant survival advantage of pLGG flank xenografts treated with the mTOR inhibitor everolimus and BRAF inhibitor PLX4720 compared to each agent alone [62].

\section{Ependymoma}

Ependymoma is the second most common malignant pediatric CNS tumor, accounting for approximately $10 \%$ of brain tumors [63]. Prognosis is relatively poor particularly at recurrence, which is common [4]. 90\% of pediatric cases are intracranial, $70 \%$ occurring in the 
posterior fossa.

An immunohistochemical analysis of phosphorylated AKT demonstrated positive staining, and inferred pathway activation, in a high percentage of ependymomas ( $72 \%$ of primary tumors), which was significantly linked to a poorer progression free survival. Cyclin D1 was significantly associated with active PI3K signaling suggesting control of cell proliferation [64]. Active PI3K signaling has also been demonstrated in ependymoma cell lines [65].

A definitive mechanism for activation of PI3K signaling has not been determined for ependymoma. Sequencing studies have not identified PIK3CA mutations $[7,64]$. Copy number loss of the PTEN loci has been reported [66], however no loss of PTEN protein expression was detected across a large ependymoma cohort [64]. Overexpression of ERBB receptors has been reported at variable frequencies $[67,68]$. ERBB2/4 co-expression has also been reported at high frequencies with high coexpression significantly related to tumor proliferation and disease risk [67]. A recent study also demonstrated that the putative ependymoma oncogene $A K T 2$ could drive formation of ependymomas in mice [69]. However, gain of $A K T 2$ has only been detected in approximately $4 \%$ of ependymomas [66].

A decrease in cell viability has been demonstrated in ependymoma cell lines following treatment with PI3K pathway inhibitors suggesting the potential for therapeutic targeting [64, 65]. A high throughput drug screen using an ependymoma mouse model also identified inhibitors of IGF, signaling through PI3K, as a significant target [70].

\section{Medulloblastoma}

Medulloblastoma is an embryonal tumor and is the most common malignant brain tumor in children [6]. Recent large scale analysis has enabled researchers to divide medulloblastomas into four molecular subgroups; WNT, SHH, Group 3 and Group 4, which correlate with demographic and clinical factors [6]. Prognosis differs significantly between these groups with the best outcome occurring for patients with WNT subgroup tumors and the poorest for those with a Group 3 tumor [6].

Active PI3K signaling has been detected in a high percentage of medulloblastomas [71-73], and has been shown to be de-regulated by a number of mechanisms. Various growth factor receptors, which can activate PI3K signaling, have been shown to be over-expressed by medulloblastoma cells, through mechanisms including copy number gain and amplification [74-76]. Decreased levels of the tumor suppressor PTEN have frequently been seen, caused by mutations, copy number loss or promoter

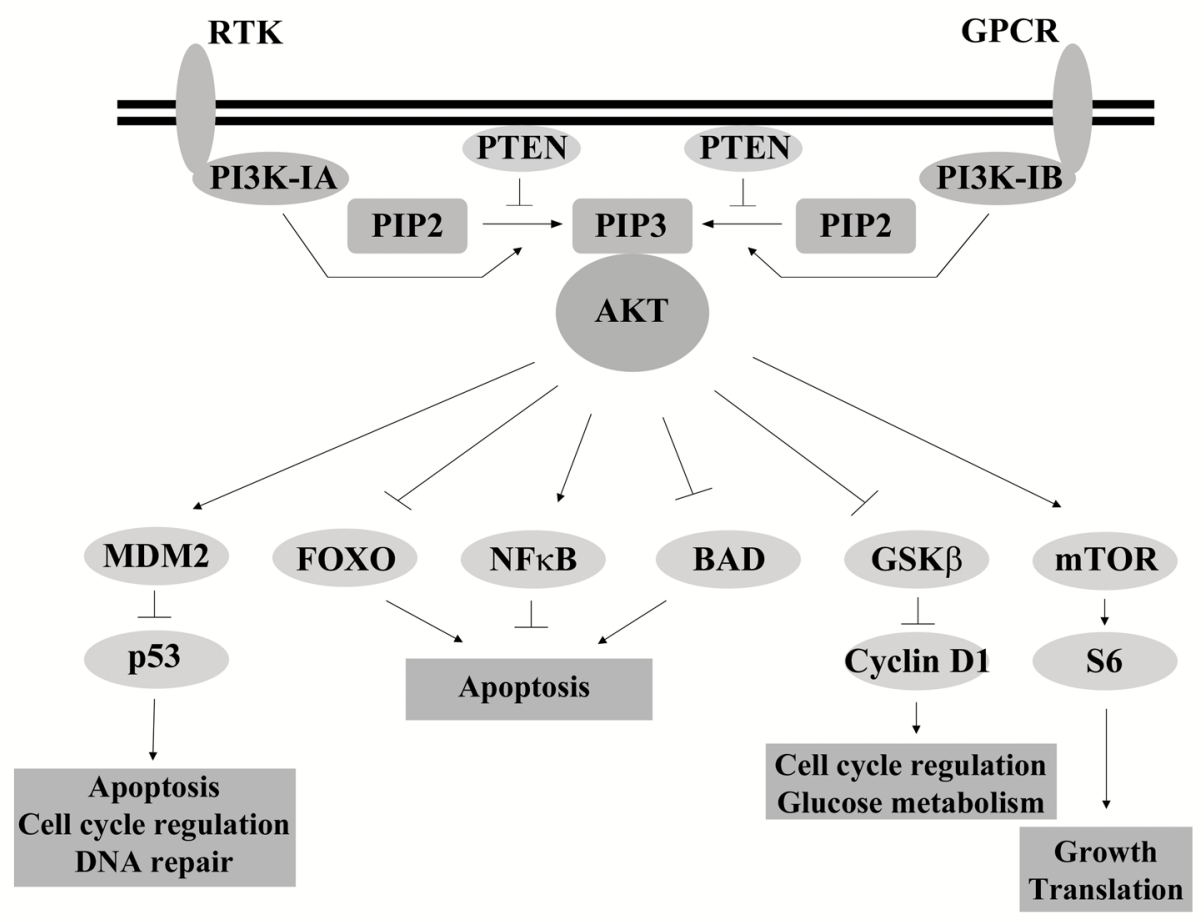

Figure 1: Overview of Class I PI3K signaling. Following activation of receptors, through ligands such as growth factors or cytokines, $\mathrm{PI} 3 \mathrm{~K}$ is recruited to the membrane where the regulatory subunit interacts with the receptor. The activated catalytic subunit converts PIP to $\mathrm{PIP}_{3}$. PTEN negatively regulates this reaction, converting PIP $_{3}$ back to PIP ${ }_{2}$. PIP $\mathrm{P}_{3}$ recruits AKT to the membrane where it is activated through phosphorylation. Once activated AKT regulates a range of targets, of which a small set of examples are presented, activating or inhibiting their action through phosphorylation. 
methylation $[73,77]$. PIK3CA mutations have also been identified at a low frequency [78]. PIK3CA overexpression was commonly seen and was associated with active PI3K signaling [72]. PIK3C2B amplifications have been detected [79] as well as overexpression of PI3KC2 $\beta$ and PIK3CG [80]. Amplification of AKT3 has also been identified [81]. Additionally, a recent study demonstrated that Myc induced PI3K signaling drove a metastatic phenotype in orthotopic models [82].

Inhibition of PI3K signaling has demonstrated a role for the pathway in control of medulloblastoma cell growth and migration. Treatment with inhibitors at various nodes of the signaling pathway, including PI3K, AKT and mTOR, resulted in impaired growth and migration of medulloblastoma cells using in vitro and in vivo models $[83,84]$. Treatment with pathway inhibitors was also shown to enhance the cytotoxic effects of chemotherapy drugs such as cisplatin and etoposide [71]. Targeting PI3K isoforms specifically has resulted in variable success. Targeting the Class IA isoform $\mathrm{p} 110 \alpha$ or the Class IB isoform $\mathrm{p} 110 \gamma$ resulted in decreased medulloblastoma cell proliferation and enhanced effects of chemotherapy [72, $84,85]$. However, targeting of other Class IA isoforms was not so effective [72]. Reduced proliferation was also seen following inhibition of the Class II isoform PIK3C2 $\beta$ [86].

PI3K signaling has also been linked to tumor resistance in medulloblastoma. Inhibition of PI3K signaling in a sonic hedgehog pathway induced medulloblastoma mouse model delayed the development of smo-induced resistance [87].

\section{Atypical teratoid/rhabdoid tumor (ATRT)}

ATRT is a highly malignant embryonal tumor, distinguished by alterations in the tumor suppressor gene INI1 [3]. It is currently considered one of the most malignant and difficult pediatric tumors to cure [88]. Patients respond poorly to chemotherapy and radiotherapy and prognosis is poor [3].

Studies have implicated PI3K signaling in the control of ATRT cell growth. ATRT cell lines were found to overexpress RTKs, including insulin receptor and insulin-like growth factor-I receptor, as well as PI3K signaling components, compared to normal brain. PI3K signaling was also shown to play a crucial role in ATRT cell proliferation induced by insulin signaling with evidence that induced signaling was mediated specifically through the Class IA PI3K isoform p $110 \alpha$ [89]. Pharmacological inhibitors of PI3K signaling have also been shown to impair the growth of ATRT cells [88].

\section{Embryonal tumors}

Embryonal tumors previously classified as central nervous system primitive neuroectodermal tumors (CNS-
PNET) have undergone a major re-organization in the recent WHO classification, to reflect their molecular basis [90]. They encompass a range of histological subtypes including embryonal tumor with multi-layered rosettes (ETMR), CNS neuroblastoma, CNS ganglioneuroblastoma and medulloepithelioma.

Amplification of the C19MC oncogenic miRNA cluster and high LIN28 expression has been linked to an aggressive group of embryonal tumors which span histological subtypes [9]. PI3K/mTOR pathway genes were found to be enriched within this subgroup. Immunohistochemical analysis additionally revealed upregulation of phosphorylated S6 (indicating active mTOR signaling) [9]. Pharmacological inhibition of PI3K/mTOR signaling inhibited the growth of CNS PNET cells in culture suggesting this is a potential therapeutic target [9, 91].

\section{THERAPEUTIC TARGETING OF PI3K SIGNALING IN PEDIATRIC BRAIN TUMORS}

The high frequency of alterations in PI3K signaling in pediatric brain tumors has led to the initiation of clinical trials testing these agents (Table 1). The most advanced target downstream mTOR signaling.

Everolimus has recently been approved for treatment of TSC patients with SEGA [36]. Everolimus was also well tolerated when tested in a phase I trial of children with recurrent/refractory solid tumors and was shown to significantly inhibit mTOR signaling at the maximum tolerated dose (MTD) [92]. A recent phase II trial for children with recurrent LGG demonstrated stable disease in $13 / 23$ patients and a partial response in four [93]. Current trials are continuing to investigate the drug in pediatric brain tumors including phase II trials investigating progressive LGG (NCT01734512) and recurrent or progressive ependymoma (NCT02155920). Additionally, two trials are investigating treatment with everolimus following selection based on the presence of relevant abnormalities in patients with refractory or recurrent brain tumors (NCT02015728) or DIPG (NCT02233049/BIOMEDE).

Temsirolimus was the first mTOR inhibitor approved for treatment in oncology. In phase I trials of pediatric patients with recurrent/refractory solid tumors temsirolimus was shown to be well tolerated [94]. In a phase II trial of children with HGG, neuroblastoma and rhabdomyosarcoma, temsirolimus treatment did not meet the objective efficacy threshold for continuation [95]. However, prolonged disease stabilization was observed and supported further study. A phase I trial of temsirolimus in combination with irinotecan and temozolomide in children, adolescents and young adults with relapsed/ refractory solid tumors found the combination well tolerated [96]. Similarly a phase I study of children with 
Table 1: Current and completed clinical trials targeting PI3K signaling in pediatric CNS tumors

\begin{tabular}{|c|c|c|c|c|c|}
\hline Drug & Target & Study type & Tumor type & Result & Reference \\
\hline MK2206 & AKT & Phase I & Refractory tumors & $\begin{array}{l}\text { Well tolerated. Phase II dose } \\
\text { identified }\end{array}$ & 103 \\
\hline Perifosine & AKT & Phase I & \begin{tabular}{|l|}
$\begin{array}{l}\text { Recurrent solid } \\
\text { tumors }\end{array}$ \\
\end{tabular} & & NCT00776867 \\
\hline $\begin{array}{l}\text { Perifosine } \\
(+ \text { temsirolimus })\end{array}$ & AKT & Phase I & \begin{tabular}{|l|}
$\begin{array}{l}\text { Recurrent solid } \\
\text { tumors }\end{array}$ \\
\end{tabular} & & NCT01049841 \\
\hline Everolimus & mTOR & & SEGA & Approved for treatment & 36 \\
\hline Everolimus & mTOR & Phase I & $\begin{array}{l}\text { Recurrent/refractory } \\
\text { solid tumors }\end{array}$ & $\begin{array}{l}\text { Well tolerated with significant } \\
\text { inhibition of mTOR signaling. } \\
\text { MTD identified }\end{array}$ & 92 \\
\hline Everolimus & mTOR & Phase II & Recurrent LGG & $\begin{array}{l}\text { Stable disease in } 12 / 23 \text { patients } \\
\text { and partial response in } 4 / 23\end{array}$ & 93 \\
\hline Everolimus & mTOR & Phase II & Progressive LGG & - & NCT01734512 \\
\hline Everolimus & mTOR & Phase II & $\begin{array}{l}\text { Recurrent/progressive } \\
\text { ependymoma }\end{array}$ & - & NCT02155920 \\
\hline Everolimus & mTOR & Feasibility & $\begin{array}{l}\text { Refractory/recurrent } \\
\text { brain tumors }\end{array}$ & - & NCT02015728 \\
\hline Everolimus & mTOR & Phase II & DIPG & - & NCT02233049 \\
\hline Temsirolimus & mTOR & Phase I & $\begin{array}{l}\text { Recurrent/refractory } \\
\text { solid tumors }\end{array}$ & $\begin{array}{l}\text { Well tolerated. Anti-tumor } \\
\text { activity and inhibition of mTOR } \\
\text { signalling. MTD not identified } \\
\end{array}$ & 94 \\
\hline Temsirolimus & mTOR & Phase II & $\begin{array}{l}\text { HGG, neuroblastoma, } \\
\text { rahbdomyosarcoma }\end{array}$ & $\begin{array}{l}\text { Did not meet objective efficacy } \\
\text { threshold for continuation, but } \\
\text { suggested further study. }\end{array}$ & 95 \\
\hline $\begin{array}{l}\text { Temsirolimus } \\
\text { (+irinotecan, } \\
\text { temozolomide) }\end{array}$ & mTOR & Phase I & $\begin{array}{l}\text { Relapsed/refractory } \\
\text { solid tumors }\end{array}$ & Well tolerated. MTD identified. & 96 \\
\hline $\begin{array}{l}\text { Temsirolimus } \\
\text { (+cixutumumab) }\end{array}$ & mTOR & Phase I & \begin{tabular}{|l|}
$\begin{array}{l}\text { Recurrent solid } \\
\text { tumors }\end{array}$ \\
\end{tabular} & $\begin{array}{l}\text { Well tolerated. Phase II dose } \\
\text { identified. }\end{array}$ & 97 \\
\hline $\begin{array}{l}\text { Temsirolimus } \\
(+ \text { cixutumumab) }\end{array}$ & mTOR & Phase I & $\begin{array}{l}\text { Recurrent/refractory } \\
\text { solid tumors }\end{array}$ & & NCT00880282 \\
\hline $\begin{array}{l}\text { Temsirolimus } \\
\text { (=bevacizumab, } \\
\text { cyclophosphamide, } \\
\text { valproic acid) }\end{array}$ & mTOR & Phase 0 & $\begin{array}{l}\text { Solid tumors at high } \\
\text { risk of recurrence }\end{array}$ & & NCT02446431 \\
\hline Rapamycin (+erlotinib) & mTOR & \begin{tabular}{|l|} 
Feasibility/ \\
Phase II \\
\end{tabular} & Recurrent LGG & $\begin{array}{l}\text { Well tolerated. Questionable to } \\
\text { no activity. }\end{array}$ & 98 \\
\hline Rapamycin (+vinblastine) & mTOR & Phase I & $\begin{array}{l}\text { Recurrent/refractory } \\
\text { solid tumors }\end{array}$ & $\begin{array}{l}\text { Well tolerated. Anti-tumor } \\
\text { effects seen. }\end{array}$ & 99 \\
\hline $\begin{array}{l}\text { Rapamycin } \\
\text { (+chemotherapy) }\end{array}$ & mTOR & Phase I & $\begin{array}{l}\text { Recurrent/refractory } \\
\text { solid tumors }\end{array}$ & & NCT01331135 \\
\hline Rapamycin (+irinotecan) & mTOR & Phase I & \begin{tabular}{|l|}
$\begin{array}{l}\text { Refractory solid } \\
\text { tumors }\end{array}$ \\
\end{tabular} & & NCT01282697 \\
\hline $\begin{array}{l}\text { Rapamycin } \\
\text { (+cyclophosphamide, } \\
\text { topotecan) }\end{array}$ & mTOR & Phase I & $\begin{array}{l}\text { Recurrent/refractory } \\
\text { solid tumors }\end{array}$ & & NCT01670175 \\
\hline Ridaforolimus & mTOR & Phase I & $\begin{array}{l}\text { Refractory solid } \\
\text { tumors }\end{array}$ & $\begin{array}{l}\text { Well tolerated with no dose } \\
\text { limiting toxicities identified. } \\
\text { MTD not identified. }\end{array}$ & 100 \\
\hline Ridaforolimus & mTOR & Phase I & $\begin{array}{l}\text { Advanced solid } \\
\text { tumors }\end{array}$ & $\begin{array}{l}\text { We tolerated. MTD not } \\
\text { identified. Phase II dose } \\
\text { determined. }\end{array}$ & 101 \\
\hline $\begin{array}{l}\text { Ridaforolimus } \\
(+ \text { dalotuzumab) }\end{array}$ & mTOR & Phase I & \begin{tabular}{|l|}
$\begin{array}{l}\text { Advanced solid } \\
\text { tumors }\end{array}$ \\
\end{tabular} & $\begin{array}{|ll|}\begin{array}{l}\text { Demonstrated } \\
\text { tolerability }\end{array} & \text { reasonable } \\
\end{array}$ & 102 \\
\hline Everolimus and AZD2014 & mTOR & Phase I/II & $\begin{array}{l}\text { Recurrent/refractory } \\
\text { tumors }\end{array}$ & & NCT02813135 \\
\hline
\end{tabular}

$\mathrm{SEGA}=$ subependymal giant cell astrocytoma, $\mathrm{MTD}=$ maximum tolerated dose, $\mathrm{LGG}=$ low grade glioma, $\mathrm{HGG}=$ high grade glioma, DIPG = diffuse intrinsic pontine glioma 
recurrent solid tumors demonstrated the combination of temsirolimus with cixutumumab, a monoclonal antibody targeted against the insulin-like growth factor-1 receptor (IGF-1R), to be well tolerated [97]. A second phase I study investigating the combination of temsirolimus with cixutumumab in younger patients with solid tumors which have recurred or not responded to treatment is ongoing (NCT00880282). Additionally, a phase 0 study has begun looking at the potential for use of metronomic therapy, defined as lower dose continuous drug exposure, which includes temsirolimus, in patients with solid tumors at high risk of recurrence (NCT02446431).

A study investigating the efficacy of rapamycin in combination with the EGFR inhibitor erlotinib in children with recurrent LGG was well tolerated but had questionable to no activity [98]. A second phase I trial investigating the combination of rapamycin with vinblastine, in pediatric patients with recurrent or refractory solid tumors, was found to be safe and well tolerated with preliminary evidence of anti-tumor effects [99]. Ongoing phase I trials are investigating rapamycin in combination with chemotherapy in children with recurrent/ refractory solid tumors (NCT01331135, NCT01282697, NCT01670175).

A phase I study of ridaforolimus in pediatric patients with refractory solid tumors demonstrated the drug to be well tolerated [100]. In a second phase I trial of pediatric patients with advanced solid tumors ridaforolimus was well tolerated and a phase II dose was identified [101]. A further phase I trial investigating ridaforolimus in combination with the IGF-1R inhibitor dalotuzumab showed reasonable tolerability [102].

A recently opened proof of concept therapeutic stratification trial in children, adolescents and young adults with relapsed or refractory tumors aims to use molecular analysis to identify treatment targets. The trial includes use of everolimus and the dual mTORC1 and 2 inhibitor AZD2014 (NCT02813135).

Trials investigating inhibitors of upstream PI3K signaling are less advanced. The AKT inhibitor MK2206 was investigated in a phase I trial of children with refractory malignancies where the drug was well tolerated [103]. The AKT inhibitor perifosine is currently being investigated as a single agent in a phase I trial of recurrent pediatric solid tumors (NCT00776867) and in combination with temsirolimus in a second trial (NCT01049841).

Further PI3K inhibitors have been investigated pre-clinically as part of the pediatric preclinical testing program. Studies investigating the PI3K inhibitor XL146, the AKT inhibitor GSK690693 and the mTOR inhibitor MLN0128 all demonstrated modest anti-tumor activity in preclinical models [104-106].

\section{CONCLUSIONS}

The PI3K signaling pathway has been implicated in a high proportion of pediatric CNS tumors suggesting it represents a promising target for therapy. Pathway activation has been identified in primary tumors and pre-clinical analysis has demonstrated PI3K signaling plays a role in the control of tumor growth, survival and migration.

Pre-clinical analysis of pathway inhibitors also strongly supports the potential therapeutic use of agents targeting PI3K signaling in pediatric CNS malignancies, with inhibitors able to impair the growth and migration of

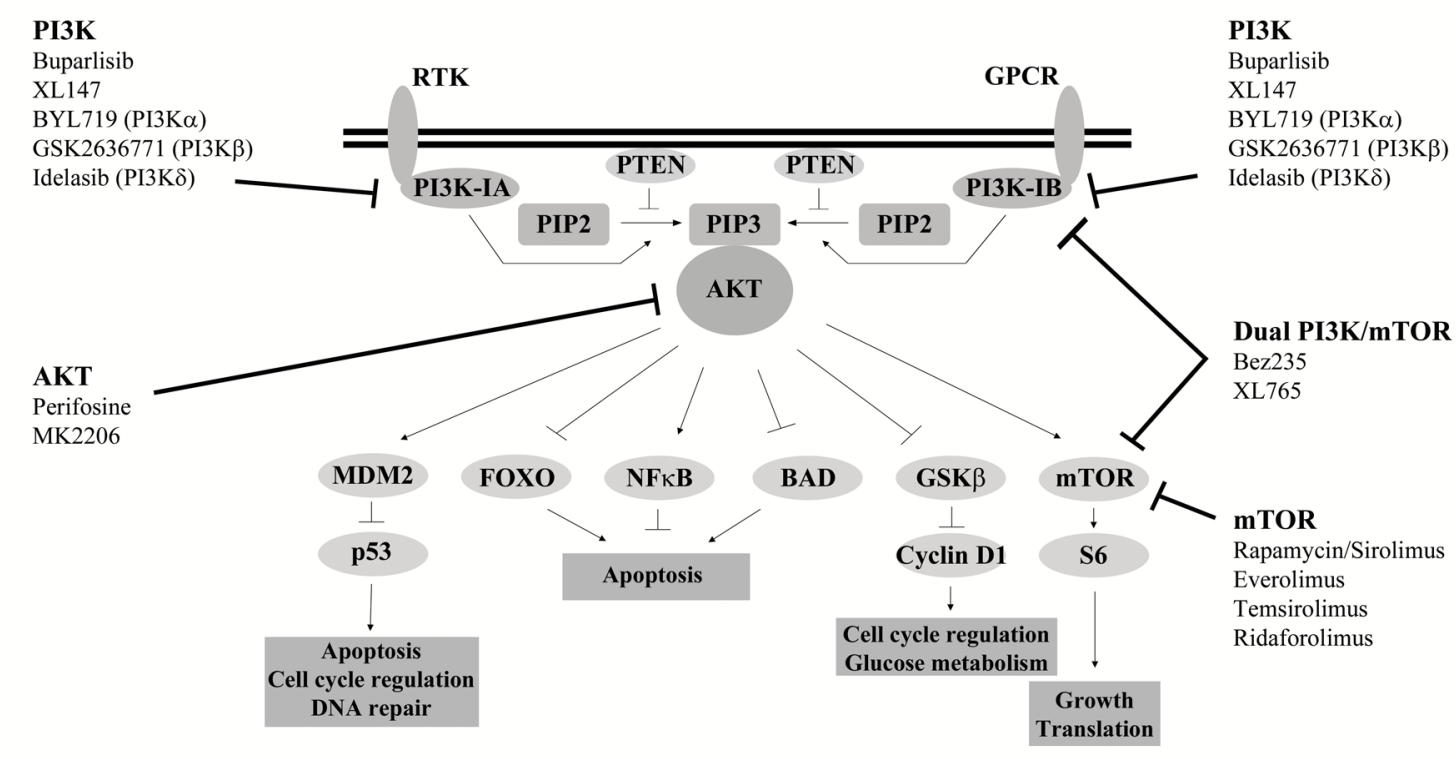

Figure 2: PI3K pathway inhibitors in clinical development. Examples of inhibitors in clinical development which target various nodes of the PI3K signalling pathway, including class I PI3K (pan or isoform), AKT and mTOR. Specific targets are given in brackets. 
tumor models as well as enhancing the cytotoxic effects of chemotherapeutic agents. Initial clinical trials have been promising with agents generally well tolerated. The evidence is particularly strong for the use of mTOR inhibitors, with approval of everolimus for the treatment of SEGA patients.

It will however be important to take into consideration problems encountered in other cancers, including adult glioma, where effects of inhibitors so far have, in general, been modest [30]. This may be due in part to poor patient selection, where predictive biomarkers have not been used to identify and select patients with a responsive tumor. Secondly, as with many targeted therapies, resistance mechanisms, such as activation of compensatory signaling, are likely to develop and therefore limit effectiveness [107]. Cross talk between different signaling pathways is complex with alternative mechanisms able to control the same downstream targets. Knowledge of how alternative signaling mechanisms are involved in a specific cancer is important when planning how to target it therapeutically. One example of this is the MAPK signaling pathway which can also activate mTOR signaling [13]. MAPK signaling is commonly activated in pediatric low grade gliomas through BRAF fusions suggesting this rather than PI3K signaling may commonly activate mTOR signaling in these tumors [108, 109]. It will also be important to investigate effects of inhibitors on tumor stroma and how this might impact clinical use of PI3K pathway inhibitors [40].

A further issue specific to brain tumors is the ability of a drug to cross the blood brain barrier and achieve high enough concentrations within the brain without systemic toxicity. Caution must also be undertaken when targeting key cellular signaling pathways that are fundamental to normal development in childhood. Evaluation of toxicity to the normal brain therefore needs to be taken into consideration.

To overcome these challenges it will firstly be important to develop sophisticated patient selection strategies, using predictive biomarkers, to ensure patients entered into a trial have a responsive tumor. Secondly, a combination approach will be needed using PI3K inhibitors alongside conventional treatments as well as other novel targeted agents to increase effectiveness and avoid development of resistance. The best and most rational combinations will need to be identified. This can only be achieved if we increase our understanding of the underlying biology of these tumors and continue analysis using pre-clinical models.

\section{FUNDING}

There was no specific funding source for the information presented in this review article. Authors were supported by funding from the University of Nottingham.

\section{CONFLICTS OF INTEREST}

The authors declare they have no conflict of interest

\section{REFERENCES}

1. Crawford J. Childhood brain tumors. Pediatr Rev. 2013; 34 : 63-78. doi: 10.1542/pir.34-2-63.

2. Broniscer A, Gajjar A. Supratentorial high-grade astrocytoma and diffuse brainstem glioma: two challenges for the pediatric oncologist. Oncologist. 2004; 9: 197-206. doi:

3. Reddy AT. Atypical teratoid/rhabdoid tumors of the central nervous system. J Neurooncol. 2005; 75: 309-13. doi: 10.1007/s11060-005-6762-8.

4. Zacharoulis S, Levy A, Chi SN, Gardner S, Rosenblum M, Miller DC, Dunkel I, Diez B, Sposto R, Ji L, Asgharzadeh $\mathrm{S}$, Hukin J, Belasco J, et al. Outcome for young children newly diagnosed with ependymoma, treated with intensive induction chemotherapy followed by myeloablative chemotherapy and autologous stem cell rescue. Pediatr Blood Cancer. 2007; 49: 34-40. doi: 10.1002/pbc.20935.

5. Faury D, Nantel A, Dunn SE, Guiot MC, Haque T, Hauser P, Garami M, Bognar L, Hanzely Z, Liberski PP, Lopez-Aguilar E, Valera ET, Tone LG, et al. Molecular profiling identifies prognostic subgroups of pediatric glioblastoma and shows increased YB-1 expression in tumors. J Clin Oncol. 2007; 25: 1196-208. doi: 10.1200/ JCO.2006.07.8626.

6. Kool M, Korshunov A, Remke M, Jones DT, Schlanstein M, Northcott PA, Cho YJ, Koster J, Schouten-van Meeteren A, van Vuurden D, Clifford SC, Pietsch T, von Bueren $\mathrm{AO}$, et al. Molecular subgroups of medulloblastoma: an international meta-analysis of transcriptome, genetic aberrations, and clinical data of WNT, SHH, Group 3, and Group 4 medulloblastomas. Acta Neuropathol. 2012; 123: 473-84. doi: 10.1007/s00401-012-0958-8.

7. Mack SC, Witt H, Piro RM, Gu L, Zuyderduyn S, Stutz AM, Wang X, Gallo M, Garzia L, Zayne K, Zhang X, Ramaswamy V, Jager $\mathrm{N}$, et al. Epigenomic alterations define lethal CIMP-positive ependymomas of infancy. Nature. 2014; 506: 445-50. doi: 10.1038/nature13108.

8. Paugh BS, Qu C, Jones C, Liu Z, Adamowicz-Brice M, Zhang J, Bax DA, Coyle B, Barrow J, Hargrave D, Lowe J, Gajjar A, Zhao W, et al. Integrated molecular genetic profiling of pediatric high-grade gliomas reveals key differences with the adult disease. J Clin Oncol. 2010; 28: 3061-8. doi: 10.1200/JCO.2009.26.7252.

9. Spence T, Sin-Chan P, Picard D, Barszczyk M, Hoss K, Lu M, Kim SK, Ra YS, Nakamura H, Fangusaro J, Hwang E, Kiehna E, Toledano H, et al. CNS-PNETs with C19MC amplification and/or LIN28 expression comprise a distinct histogenetic diagnostic and therapeutic entity. Acta Neuropathol. 2014; 128: 291-303. doi: 10.1007/s00401014-1291-1. 
10. Vanhaesebroeck B, Waterfield MD. Signaling by distinct classes of phosphoinositide 3-kinases. Exp Cell Res. 1999; 253: 239-54. doi: 10.1006/excr.1999.4701.

11. Liu P, Cheng H, Roberts TM, Zhao JJ. Targeting the phosphoinositide 3-kinase pathway in cancer. Nat Rev Drug Discov. 2009; 8: 627-44. doi: 10.1038/nrd2926.

12. Fritsch R, de Krijger I, Fritsch K, George R, Reason B, Kumar MS, Diefenbacher M, Stamp G, Downward J. RAS and RHO families of GTPases directly regulate distinct phosphoinositide 3-kinase isoforms. Cell. 2013; 153: 105063. doi: 10.1016/j.cell.2013.04.031.

13. Zoncu R, Efeyan A, Sabatini DM. mTOR: from growth signal integration to cancer, diabetes and ageing. Nat Rev Mol Cell Biol. 2011; 12: 21-35. doi: 10.1038/nrm3025.

14. Inoki $\mathrm{K}, \mathrm{Li} \mathrm{Y}, \mathrm{Zhu} \mathrm{T}, \mathrm{Wu} \mathrm{J}$, Guan $\mathrm{KL}$. TSC2 is phosphorylated and inhibited by Akt and suppresses mTOR signalling. Nat Cell Biol. 2002; 4: 648-57. doi: 10.1038/ ncb839.

15. Liu P, Gan W, Chin YR, Ogura K, Guo J, Zhang J, Wang B, Blenis J, Cantley LC, Toker A, Su B, Wei W. PtdIns $(3,4,5)$ P3-Dependent Activation of the mTORC2 Kinase Complex. Cancer Discov. 2015; 5: 1194-209. doi: 10.1158/21598290.CD-15-0460.

16. Falasca M, Maffucci T. Regulation and cellular functions of class II phosphoinositide 3-kinases. Biochem J. 2012; 443: 587-601. doi: 10.1042/BJ20120008.

17. Backer JM. The regulation and function of Class III PI3Ks: novel roles for Vps34. Biochem J. 2008; 410: 1-17. doi: 10.1042/BJ20071427.

18. Li J, Yen C, Liaw D, Podsypanina K, Bose S, Wang SI, Puc J, Miliaresis C, Rodgers L, McCombie R, Bigner SH, Giovanella BC, Ittmann M, et al. PTEN, a putative protein tyrosine phosphatase gene mutated in human brain, breast, and prostate cancer. Science. 1997; 275: 1943-7. doi: 10.1126/science.275.5308.1943.

19. Parsons DW, Jones S, Zhang X, Lin JC, Leary RJ, Angenendt P, Mankoo P, Carter H, Siu IM, Gallia GL, Olivi A, McLendon R, Rasheed BA, et al. An integrated genomic analysis of human glioblastoma multiforme. Science. 2008; 321: 1807-12. doi: 10.1126/science.1164382.

20. Samuels Y, Wang Z, Bardelli A, Silliman N, Ptak J, Szabo S, Yan H, Gazdar A, Powell SM, Riggins GJ, Willson JK, Markowitz S, Kinzler KW, et al. High frequency of mutations of the PIK3CA gene in human cancers. Science. 2004; 304: 554. doi: 10.1126/science.1096502.

21. Zhao L, Vogt PK. Hot-spot mutations in p110alpha of phosphatidylinositol 3-kinase (pI3K): differential interactions with the regulatory subunit $\mathrm{p} 85$ and with RAS. Cell Cycle. 2010; 9: 596-600. doi: 10.4161/cc.9.3.10599.

22. Thorpe LM, Yuzugullu H, Zhao JJ. PI3K in cancer: divergent roles of isoforms, modes of activation and therapeutic targeting. Nat Rev Cancer. 2015; 15: 7-24. doi: $10.1038 / \mathrm{nrc} 3860$.

23. Stemke-Hale K, Gonzalez-Angulo AM, Lluch A, Neve RM,
Kuo WL, Davies M, Carey M, Hu Z, Guan Y, Sahin A, Symmans WF, Pusztai L, Nolden LK, et al. An integrative genomic and proteomic analysis of PIK3CA, PTEN, and AKT mutations in breast cancer. Cancer Res. 2008; 68: 6084-91. doi: 10.1158/0008-5472.CAN-07-6854.

24. Brugge J, Hung MC, Mills GB. A new mutational AKTivation in the PI3K pathway. Cancer Cell. 2007; 12: 104-7. doi: 10.1016/j.ccr.2007.07.014.

25. Bos JL. ras oncogenes in human cancer: a review. Cancer Res. 1989; 49: 4682-9. doi:

26. Knobbe CB, Reifenberger G. Genetic alterations and aberrant expression of genes related to the phosphatidylinositol-3'-kinase/protein kinase B (Akt) signal transduction pathway in glioblastomas. Brain Pathol. 2003; 13: 507-18. doi: 10.1111/j.1750-3639.2003.tb00481.x.

27. Dodd KM, Dunlop EA. Tuberous sclerosis-A model for tumour growth. Semin Cell Dev Biol. 2016; 52: 3-11. doi: 10.1016/j.semcdb.2016.01.025.

28. Guo Y, Chekaluk Y, Zhang J, Du J, Gray NS, Wu CL, Kwiatkowski DJ. TSC1 involvement in bladder cancer: diverse effects and therapeutic implications. J Pathol. 2013; 230: 17-27. doi: 10.1002/path.4176.

29. Huynh H, Hao HX, Chan SL, Chen D, Ong R, Soo KC, Pochanard P, Yang D, Ruddy D, Liu M, Derti A, Balak MN, Palmer MR, et al. Loss of Tuberous Sclerosis Complex 2 (TSC2) Is Frequent in Hepatocellular Carcinoma and Predicts Response to mTORC1 Inhibitor Everolimus. Mol Cancer Ther. 2015; 14: 1224-35. doi: 10.1158/1535-7163. MCT-14-0768.

30. Yap TA, Bjerke L, Clarke PA, Workman P. Drugging PI3K in cancer: refining targets and therapeutic strategies. Curr Opin Pharmacol. 2015; 23: 98-107. doi: 10.1016/j. coph.2015.05.016.

31. Yang Q, Modi P, Newcomb T, Queva C, Gandhi V. Idelalisib: First-in-Class PI3K Delta Inhibitor for the Treatment of Chronic Lymphocytic Leukemia, Small Lymphocytic Leukemia, and Follicular Lymphoma. Clin Cancer Res. 2015; 21: 1537-42. doi: 10.1158/1078-0432. CCR-14-2034.

32. Gills JJ, Dennis PA. Perifosine: update on a novel Akt inhibitor. Curr Oncol Rep. 2009; 11: 102-10. doi: 10.1007/ s11912-009-0016-4.

33. Faivre S, Kroemer G, Raymond E. Current development of mTOR inhibitors as anticancer agents. Nat Rev Drug Discov. 2006; 5: 671-88. doi: 10.1038/nrd2062.

34. Yuan R, Kay A, Berg WJ, Lebwohl D. Targeting tumorigenesis: development and use of mTOR inhibitors in cancer therapy. J Hematol Oncol. 2009; 2: 45. doi: 10.1186/1756-8722-2-45.

35. Motzer RJ, Escudier B, Oudard S, Hutson TE, Porta C, Bracarda S, Grunwald V, Thompson JA, Figlin RA, Hollaender N, Urbanowitz G, Berg WJ, Kay A, et al. Efficacy of everolimus in advanced renal cell carcinoma: a double-blind, randomised, placebo-controlled phase 
III trial. Lancet. 2008; 372: 449-56. doi: 10.1016/S01406736(08)61039-9.

36. Wheless JW, Klimo P, Jr. Subependymal giant cell astrocytomas in patients with tuberous sclerosis complex: considerations for surgical or pharmacotherapeutic intervention. J Child Neurol. 2014; 29: 1562-71. doi: 10.1177/0883073813501870.

37. Samad N, Younes A. Temsirolimus in the treatment of relapsed or refractory mantle cell lymphoma. Onco Targets Ther. 2010; 3: 167-78. doi: 10.2147/OTT.S8147.

38. Vilar E, Perez-Garcia J, Tabernero J. Pushing the envelope in the mTOR pathway: the second generation of inhibitors. Mol Cancer Ther. 2011; 10: 395-403. doi: 10.1158/15357163.MCT-10-0905.

39. Hirsch E, Ciraolo E, Franco I, Ghigo A, Martini M. PI3K in cancer-stroma interactions: bad in seed and ugly in soil. Oncogene. 2014; 33: 3083-90. doi: 10.1038/onc.2013.265.

40. Okkenhaug K, Graupera M, Vanhaesebroeck B. Targeting PI3K in Cancer: Impact on Tumor Cells, Their Protective Stroma, Angiogenesis, and Immunotherapy. Cancer Discov. 2016; 6: 1090-105. doi: 10.1158/2159-8290.CD-16-0716.

41. Hoellenriegel J, Meadows SA, Sivina M, Wierda WG, Kantarjian H, Keating MJ, Giese N, O’Brien S, Yu A, Miller LL, Lannutti BJ, Burger JA. The phosphoinositide 3'-kinase delta inhibitor, CAL-101, inhibits B-cell receptor signaling and chemokine networks in chronic lymphocytic leukemia. Blood. 2011; 118: 3603-12. doi: 10.1182/ blood-2011-05-352492.

42. Ali K, Soond DR, Pineiro R, Hagemann T, Pearce W, Lim EL, Bouabe H, Scudamore CL, Hancox T, Maecker H, Friedman L, Turner M, Okkenhaug K, et al. Inactivation of PI(3)K p110delta breaks regulatory T-cell-mediated immune tolerance to cancer. Nature. 2014; 510: 407-11. doi: 10.1038/nature13444.

43. Pollack IF, Hamilton RL, Burger PC, Brat DJ, Rosenblum MK, Murdoch GH, Nikiforova MN, Holmes EJ, Zhou T, Cohen KJ, Jakacki RI, Children's Oncology G. Akt activation is a common event in pediatric malignant gliomas and a potential adverse prognostic marker: a report from the Children's Oncology Group. J Neurooncol. 2010; 99: 15563. doi: 10.1007/s11060-010-0297-3.

44. Thorarinsdottir HK, Santi M, McCarter R, Rushing EJ, Cornelison R, Jales A, MacDonald TJ. Protein expression of platelet-derived growth factor receptor correlates with malignant histology and PTEN with survival in childhood gliomas. Clin Cancer Res. 2008; 14: 3386-94. doi: 10.1158/1078-0432.CCR-07-1616.

45. Chakravarti A, Zhai G, Suzuki Y, Sarkesh S, Black PM, Muzikansky A, Loeffler JS. The prognostic significance of phosphatidylinositol 3-kinase pathway activation in human gliomas. J Clin Oncol. 2004; 22: 1926-33. doi: 10.1200/ JCO.2004.07.193.

46. Pollack IF, Hamilton RL, James CD, Finkelstein SD, Burnham J, Yates AJ, Holmes EJ, Zhou T, Finlay JL,
Children's Oncology G. Rarity of PTEN deletions and EGFR amplification in malignant gliomas of childhood: results from the Children's Cancer Group 945 cohort. J Neurosurg. 2006; 105: 418-24. doi: 10.3171/ ped.2006.105.5.418.

47. Mueller S, Phillips J, Onar-Thomas A, Romero E, Zheng S, Wiencke JK, McBride SM, Cowdrey C, Prados MD, Weiss WA, Berger MS, Gupta N, Haas-Kogan DA. PTEN promoter methylation and activation of the PI3K/Akt/ mTOR pathway in pediatric gliomas and influence on clinical outcome. Neuro Oncol. 2012; 14: 1146-52. doi: 10.1093/neuonc/nos140.

48. Zarghooni M, Bartels U, Lee E, Buczkowicz P, Morrison A, Huang A, Bouffet E, Hawkins C. Whole-genome profiling of pediatric diffuse intrinsic pontine gliomas highlights platelet-derived growth factor receptor alpha and poly (ADP-ribose) polymerase as potential therapeutic targets. J Clin Oncol. 2010; 28: 1337-44. doi: 10.1200/ JCO.2009.25.5463.

49. Gallia GL, Rand V, Siu IM, Eberhart CG, James CD, Marie SK, Oba-Shinjo SM, Carlotti CG, Caballero OL, Simpson AJ, Brock MV, Massion PP, Carson BS, Sr., et al. PIK3CA gene mutations in pediatric and adult glioblastoma multiforme. Mol Cancer Res. 2006; 4: 709-14. doi: 10.1158/1541-7786.MCR-06-0172.

50. Grill J, Puget S, Andreiuolo F, Philippe C, MacConaill L, Kieran MW. Critical oncogenic mutations in newly diagnosed pediatric diffuse intrinsic pontine glioma. Pediatr Blood Cancer. 2012; 58: 489-91. doi: 10.1002/pbc.24060.

51. Bax DA, Gaspar N, Little SE, Marshall L, Perryman L, Regairaz M, Viana-Pereira M, Vuononvirta R, Sharp SY, Reis-Filho JS, Stavale JN, Al-Sarraj S, Reis RM, et al. EGFRvIII deletion mutations in pediatric high-grade glioma and response to targeted therapy in pediatric glioma cell lines. Clin Cancer Res. 2009; 15: 5753-61. doi: 10.1158/1078-0432.CCR-08-3210.

52. Wu G, Diaz AK, Paugh BS, Rankin SL, Ju B, Li Y, Zhu X, Qu C, Chen X, Zhang J, Easton J, Edmonson M, Ma X, et al. The genomic landscape of diffuse intrinsic pontine glioma and pediatric non-brainstem high-grade glioma. Nat Genet. 2014; 46: 444-50. doi: 10.1038/ng.2938.

53. Paugh BS, Zhu X, Qu C, Endersby R, Diaz AK, Zhang J, Bax DA, Carvalho D, Reis RM, Onar-Thomas A, Broniscer A, Wetmore C, Zhang J, et al. Novel oncogenic PDGFRA mutations in pediatric high-grade gliomas. Cancer Res. 2013; 73: 6219-29. doi: 10.1158/0008-5472.CAN-13-1491.

54. Nikbakht H, Panditharatna E, Mikael LG, Li R, Gayden T, Osmond M, Ho CY, Kambhampati M, Hwang EI, Faury D, Siu A, Papillon-Cavanagh S, Bechet D, et al. Spatial and temporal homogeneity of driver mutations in diffuse intrinsic pontine glioma. Nat Commun. 2016; 7: 11185. doi: 10.1038/ncomms 11185 .

55. Kilday JP, Bartels UK, Bouffet E. Targeted therapy in pediatric low-grade glioma. Curr Neurol Neurosci Rep. 2014; 14: 441. doi: 10.1007/s11910-014-0441-0. 
56. Zhang J, Wu G, Miller CP, Tatevossian RG, Dalton JD, Tang B, Orisme W, Punchihewa C, Parker M, Qaddoumi I, Boop FA, Lu C, Kandoth C, et al. Whole-genome sequencing identifies genetic alterations in pediatric lowgrade gliomas. Nat Genet. 2013; 45: 602-12. doi: 10.1038/ ng.2611.

57. Adriaensen ME, Schaefer-Prokop CM, Stijnen T, Duyndam DA, Zonnenberg BA, Prokop M. Prevalence of subependymal giant cell tumors in patients with tuberous sclerosis and a review of the literature. Eur J Neurol. 2009; 16: 691-6. doi: 10.1111/j.1468-1331.2009.02567.x.

58. Hutt-Cabezas M, Karajannis MA, Zagzag D, Shah S, Horkayne-Szakaly I, Rushing EJ, Cameron JD, Jain D, Eberhart CG, Raabe EH, Rodriguez FJ. Activation of mTORC1/mTORC2 signaling in pediatric low-grade glioma and pilocytic astrocytoma reveals mTOR as a therapeutic target. Neuro Oncol. 2013; 15: 1604-14. doi: 10.1093/neuonc/not132.

59. Jentoft M, Giannini C, Cen L, Scheithauer BW, Hoesley B, Sarkaria JN, Abell-Aleff PC, Rodriguez EF, Li Y, Rodriguez FJ. Phenotypic variations in NF1-associated low grade astrocytomas: possible role for increased mTOR activation in a subset. Int J Clin Exp Pathol. 2010; 4: 43-57. doi:

60. Rodriguez EF, Scheithauer BW, Giannini C, Rynearson A, Cen L, Hoesley B, Gilmer-Flynn H, Sarkaria JN, Jenkins S, Long J, Rodriguez FJ. PI3K/AKT pathway alterations are associated with clinically aggressive and histologically anaplastic subsets of pilocytic astrocytoma. Acta Neuropathol. 2011; 121: 407-20. doi: 10.1007/s00401010-0784-9.

61. Kaul A, Chen YH, Emnett RJ, Dahiya S, Gutmann DH. Pediatric glioma-associated KIAA1549:BRAF expression regulates neuroglial cell growth in a cell type-specific and mTOR-dependent manner. Genes Dev. 2012; 26: 2561-6. doi: 10.1101/gad.200907.112.

62. Dasgupta T, Olow A, Tang X, Nicolaides T, Hass-Kogan DA. Survival advantage with Everolimus (RAD001) combined with a selective BRAFV600E Inhibitor in a Xenograft Model of BRAFV600E-mutated Pediatric Glioma. Neuro-Oncology. 2013; 15 (Suppl. 1) (abstract 0161). doi: 10.1093/neuonc/not047.

63. Peris-Bonet R, Martinez-Garcia C, Lacour B, Petrovich S, Giner-Ripoll B, Navajas A, Steliarova-Foucher E. Childhood central nervous system tumours-incidence and survival in Europe (1978-1997): report from Automated Childhood Cancer Information System project. Eur J Cancer. 2006; 42: 2064-80. doi: 10.1016/j.ejca.2006.05.009.

64. Rogers HA, Mayne C, Chapman RJ, Kilday JP, Coyle B, Grundy RG. PI3K pathway activation provides a novel therapeutic target for pediatric ependymoma and is an independent marker of progression-free survival. Clin Cancer Res. 2013; 19: 6450-60. doi: 10.1158/1078-0432. CCR-13-0222.

65. Guan S, Shen R, Lafortune T, Tiao N, Houghton P, Yung
WK, Koul D. Establishment and characterization of clinically relevant models of ependymoma: a true challenge for targeted therapy. Neuro Oncol. 2011; 13: 748-58. doi: 10.1093/neuonc/nor037.

66. Johnson RA, Wright KD, Poppleton H, Mohankumar KM, Finkelstein D, Pounds SB, Rand V, Leary SE, White E, Eden C, Hogg T, Northcott P, Mack S, et al. Cross-species genomics matches driver mutations and cell compartments to model ependymoma. Nature. 2010; 466: 632-6. doi: 10.1038/nature09173.

67. Gilbertson RJ, Bentley L, Hernan R, Junttila TT, Frank AJ, Haapasalo H, Connelly M, Wetmore C, Curran T, Elenius K, Ellison DW. ERBB receptor signaling promotes ependymoma cell proliferation and represents a potential novel therapeutic target for this disease. Clin Cancer Res. 2002; 8: 3054-64. doi:

68. Modena P, Buttarelli FR, Miceli R, Piccinin E, Baldi C, Antonelli M, Morra I, Lauriola L, Di Rocco C, Garre ML, Sardi I, Genitori L, Maestro R, et al. Predictors of outcome in an AIEOP series of childhood ependymomas: a multifactorial analysis. Neuro Oncol. 2012; 14: 1346-56. doi: 10.1093/neuonc/nos245.

69. Mohankumar KM, Currle DS, White E, Boulos N, Dapper J, Eden C, Nimmervoll B, Thiruvenkatam R, Connelly M, Kranenburg TA, Neale G, Olsen S, Wang YD, et al. An in vivo screen identifies ependymoma oncogenes and tumorsuppressor genes. Nat Genet. 2015. doi: 10.1038/ng.3323.

70. Atkinson JM, Shelat AA, Carcaboso AM, Kranenburg TA, Arnold LA, Boulos N, Wright K, Johnson RA, Poppleton H, Mohankumar KM, Feau C, Phoenix T, Gibson P, et al. An integrated in vitro and in vivo high-throughput screen identifies treatment leads for ependymoma. Cancer Cell. 2011; 20: 384-99. doi: 10.1016/j.ccr.2011.08.013.

71. Baryawno N, Sveinbjornsson B, Eksborg S, Chen CS, Kogner P, Johnsen JI. Small-molecule inhibitors of phosphatidylinositol 3-kinase/Akt signaling inhibit Wnt/beta-catenin pathway cross-talk and suppress medulloblastoma growth. Cancer Res. 2010; 70: 266-76. doi: 10.1158/0008-5472.CAN-09-0578.

72. Guerreiro AS, Fattet S, Fischer B, Shalaby T, Jackson SP, Schoenwaelder SM, Grotzer MA, Delattre O, Arcaro A. Targeting the PI3K p110alpha isoform inhibits medulloblastoma proliferation, chemoresistance, and migration. Clin Cancer Res. 2008; 14: 6761-9. doi: 10.1158/1078-0432.CCR-08-0385.

73. Hartmann W, Digon-Sontgerath B, Koch A, Waha A, Endl E, Dani I, Denkhaus D, Goodyer CG, Sorensen N, Wiestler OD, Pietsch T. Phosphatidylinositol 3'-kinase/AKT signaling is activated in medulloblastoma cell proliferation and is associated with reduced expression of PTEN. Clin Cancer Res. 2006; 12: 3019-27. doi: 10.1158/1078-0432. CCR-05-2187.

74. Blom T, Roselli A, Hayry V, Tynninen O, Wartiovaara K, Korja M, Nordfors K, Haapasalo H, Nupponen NN. Amplification and overexpression of KIT, PDGFRA, 
and VEGFR2 in medulloblastomas and primitive neuroectodermal tumors. J Neurooncol. 2010; 97: 217-24. doi: 10.1007/s11060-009-0014-2.

75. Liu W, Zhang S, Zhang L, Cui Q, Wang J, Gui T, Pang Q. A prognostic analysis of pediatrics central nervous system small cell tumors: evaluation of EGFR family gene amplification and overexpression. Diagn Pathol. 2014; 9: 132. doi: 10.1186/1746-1596-9-132.

76. Gilbertson RJ, Perry RH, Kelly PJ, Pearson AD, Lunec J. Prognostic significance of HER2 and HER4 coexpression in childhood medulloblastoma. Cancer Res. 1997; 57: 327280. doi:

77. Parsons DW, Li M, Zhang X, Jones S, Leary RJ, Lin JC, Boca SM, Carter H, Samayoa J, Bettegowda C, Gallia GL, Jallo GI, Binder ZA, et al. The genetic landscape of the childhood cancer medulloblastoma. Science. 2011; 331: 435-9. doi: 10.1126/science.1198056.

78. Broderick DK, Di C, Parrett TJ, Samuels YR, Cummins JM, McLendon RE, Fults DW, Velculescu VE, Bigner DD, Yan H. Mutations of PIK3CA in anaplastic oligodendrogliomas, high-grade astrocytomas, and medulloblastomas. Cancer Res. 2004; 64: 5048-50. doi: 10.1158/0008-5472.CAN-041170.

79. Northcott PA, Jones DT, Kool M, Robinson GW, Gilbertson RJ, Cho YJ, Pomeroy SL, Korshunov A, Lichter P, Taylor MD, Pfister SM. Medulloblastomics: the end of the beginning. Nat Rev Cancer. 2012; 12: 818-34. doi: 10.1038/nrc3410.

80. Shymanets A, Prajwal, Bucher K, Beer-Hammer S, Harteneck C, Nurnberg B. p87 and p101 subunits are distinct regulators determining class IB phosphoinositide 3-kinase (PI3K) specificity. J Biol Chem. 2013; 288: 3105968. doi: 10.1074/jbc.M113.508234.

81. Kagawa N, Maruno M, Suzuki T, Hashiba T, Hashimoto $\mathrm{N}$, Izumoto S, Yoshimine T. Detection of genetic and chromosomal aberrations in medulloblastomas and primitive neuroectodermal tumors with DNA microarrays. Brain Tumor Pathol. 2006; 23: 41-7. doi: 10.1007/s10014006-0201-1.

82. Chan TS, Hawkins C, Krieger JR, McGlade CJ, Huang A. JPO2/CDCA7L and LEDGF/p75 Are Novel Mediators of PI3K/AKT Signaling and Aggressive Phenotypes in Medulloblastoma. Cancer Res. 2016; 76: 2802-12. doi: 10.1158/0008-5472.CAN-15-2194.

83. Ehrhardt M, Craveiro RB, Holst MI, Pietsch T, Dilloo D. The PI3K inhibitor GDC-0941 displays promising in vitro and in vivo efficacy for targeted medulloblastoma therapy. Oncotarget. 2015; 6: 802-13. doi: 10.18632/ oncotarget.2742.

84. Wojtalla A, Salm F, Christiansen DG, Cremona T, Cwiek P, Shalaby T, Gross N, Grotzer MA, Arcaro A. Novel agents targeting the IGF-1R/PI3K pathway impair cell proliferation and survival in subsets of medulloblastoma and neuroblastoma. PLoS One. 2012; 7: e47109. doi: 10.1371/journal.pone.0047109.
85. Guerreiro AS, Fattet S, Kulesza DW, Atamer A, Elsing AN, Shalaby T, Jackson SP, Schoenwaelder SM, Grotzer MA, Delattre O, Arcaro A. A sensitized RNA interference screen identifies a novel role for the PI3K p110gamma isoform in medulloblastoma cell proliferation and chemoresistance. Mol Cancer Res. 2011; 9: 925-35. doi: 10.1158/1541-7786. MCR-10-0200.

86. Boller D, Doepfner KT, De Laurentiis A, Guerreiro AS, Marinov M, Shalaby T, Depledge P, Robson A, Saghir N, Hayakawa M, Kaizawa H, Koizumi T, Ohishi T, et al. Targeting PI3KC2beta impairs proliferation and survival in acute leukemia, brain tumours and neuroendocrine tumours. Anticancer Res. 2012; 32: 3015-27. doi:

87. Buonamici S, Williams J, Morrissey M, Wang A, Guo R, Vattay A, Hsiao K, Yuan J, Green J, Ospina B, Yu Q, Ostrom L, Fordjour P, et al. Interfering with resistance to smoothened antagonists by inhibition of the PI3K pathway in medulloblastoma. Sci Transl Med. 2010; 2: 51ra70. doi: 10.1126/scitranslmed.3001599.

88. Singh A, Lun X, Jayanthan A, Obaid H, Ruan Y, Strother D, Chi SN, Smith A, Forsyth P, Narendran A. Profiling pathway-specific novel therapeutics in preclinical assessment for central nervous system atypical teratoid rhabdoid tumors (CNS ATRT): favorable activity of targeting EGFR- ErbB2 signaling with lapatinib. Mol Oncol. 2013; 7: 497-512. doi: 10.1016/j.molonc.2013.01.001.

89. Arcaro A, Doepfner KT, Boller D, Guerreiro AS, Shalaby T, Jackson SP, Schoenwaelder SM, Delattre O, Grotzer MA, Fischer B. Novel role for insulin as an autocrine growth factor for malignant brain tumour cells. Biochem J. 2007; 406: 57-66. doi: 10.1042/BJ20070309.

90. Louis DN, Perry A, Reifenberger G, von Deimling A, Figarella-Branger D, Cavenee WK, Ohgaki H, Wiestler OD, Kleihues P, Ellison DW. The 2016 World Health Organization Classification of Tumors of the Central Nervous System: a summary. Acta Neuropathol. 2016; 131: 803-20. doi: 10.1007/s00401-016-1545-1.

91. Spence T, Perotti C, Sin-Chan P, Picard D, Wu W, Singh A, Anderson C, Blough MD, Cairncross JG, Lafay-Cousin L, Strother D, Hawkins C, Narendran A, et al. A novel C19MC amplified cell line links Lin28/let-7 to mTOR signaling in embryonal tumor with multilayered rosettes. Neuro Oncol. 2014; 16: 62-71. doi: 10.1093/neuonc/not162.

92. Fouladi M, Laningham F, Wu J, O'Shaughnessy MA, Molina K, Broniscer A, Spunt SL, Luckett I, Stewart CF, Houghton PJ, Gilbertson RJ, Furman WL. Phase I study of everolimus in pediatric patients with refractory solid tumors. J Clin Oncol. 2007; 25: 4806-12. doi: 10.1200/ JCO.2007.11.4017.

93. Kieran M, Yao X, Macy M. A propsective multiinstitutional Phase II study of everolimus (Rad001), an mTOR inhibitor, in pediatric patients with recurrent or progressive low-grade glioma. Pediatric blood \& cancer. 2013; 60 (Abstract O-0068). doi: 10.1002/pbc.24719.

94. Spunt SL, Grupp SA, Vik TA, Santana VM, Greenblatt DJ, 
Clancy J, Berkenblit A, Krygowski M, Ananthakrishnan R, Boni JP, Gilbertson RJ. Phase I study of temsirolimus in pediatric patients with recurrent/refractory solid tumors. J Clin Oncol. 2011; 29: 2933-40. doi: 10.1200/ JCO.2010.33.4649.

95. Geoerger B, Kieran MW, Grupp S, Perek D, Clancy J, Krygowski M, Ananthakrishnan R, Boni JP, Berkenblit A, Spunt SL. Phase II trial of temsirolimus in children with high-grade glioma, neuroblastoma and rhabdomyosarcoma. Eur J Cancer. 2012; 48: 253-62. doi: 10.1016/j. ejca.2011.09.021

96. Bagatell R, Norris R, Ingle AM, Ahern C, Voss S, Fox E, Little AR, Weigel BJ, Adamson PC, Blaney S. Phase 1 trial of temsirolimus in combination with irinotecan and temozolomide in children, adolescents and young adults with relapsed or refractory solid tumors: a Children's Oncology Group Study. Pediatr Blood Cancer. 2014; 61: 833-9. doi: 10.1002/pbc.24874.

97. Fouladi M, Perentesis JP, Wagner LM, Vinks AA, Reid JM, Ahern C, Thomas G, Mercer CA, Krueger DA, Houghton PJ, Doyle LA, Chen H, Weigel B, et al. A Phase I Study of Cixutumumab (IMC-A12) in Combination with Temsirolimus (CCI-779) in Children with Recurrent Solid Tumors: A Children's Oncology Group Phase I Consortium Report. Clin Cancer Res. 2015; 21: 1558-65. doi: 10.1158/1078-0432.CCR-14-0595.

98. Yalon M, Rood B, MacDonald TJ, McCowage G, Kane R, Constantini S, Packer RJ. A feasibility and efficacy study of rapamycin and erlotinib for recurrent pediatric low-grade glioma (LGG). Pediatr Blood Cancer. 2013; 60: 71-6. doi: 10.1002/pbc.24142.

99. Morgenstern DA, Marzouki M, Bartels U, Irwin MS, Sholler GL, Gammon J, Yankanah R, Wu B, Samson Y, Baruchel S. Phase I study of vinblastine and sirolimus in pediatric patients with recurrent or refractory solid tumors. Pediatr Blood Cancer. 2014; 61: 128-33. doi: 10.1002/ pbc. 24656.

100. Gore L, Trippett TM, Katzenstein HM, Boklan J, Narendran A, Smith A, Macy ME, Rolla K, Pediatric Oncology Experimental Therapeutics Investigators $\mathrm{C}$, Narashimhan $\mathrm{N}$, Squillace RM, Turner CD, Haluska FG, et al. A multicenter, first-in-pediatrics, phase 1, pharmacokinetic and pharmacodynamic study of ridaforolimus in patients with refractory solid tumors. Clin Cancer Res. 2013; 19: 3649-58. doi: 10.1158/1078-0432.CCR-12-3166.

101. Pearson AD, Federico SM, Aerts I, Hargrave DR, DuBois $\mathrm{SG}$, Iannone $\mathrm{R}$, Geschwindt RD, Wang R, Haluska FG, Trippett TM, Geoerger B. A phase 1 study of oral ridaforolimus in pediatric patients with advanced solid tumors. Oncotarget. 2016; 7:84736-84747. doi: 10.18632/ oncotarget.12450.

102. Frappaz D, Federico SM, Pearson AD, Gore L, Macy ME, DuBois SG, Aerts I, Iannone R, Geschwindt R, Van Schanke A, Wang R, Geoerger B. Phase 1 study of dalotuzumab monotherapy and ridaforolimus-dalotuzumab combination therapy in paediatric patients with advanced solid tumours. Eur J Cancer. 2016; 62: 9-17. doi: 10.1016/j. ejca.2016.03.084.

103. Fouladi M, Perentesis JP, Phillips CL, Leary S, Reid $\mathrm{JM}$, McGovern RM, Ingle AM, Ahern $\mathrm{CH}$, Ames MM, Houghton P, Doyle LA, Weigel B, Blaney SM. A phase I trial of MK-2206 in children with refractory malignancies: a Children's Oncology Group study. Pediatr Blood Cancer. 2014; 61: 1246-51. doi: 10.1002/pbc.25023.

104. Carol H, Morton CL, Gorlick R, Kolb EA, Keir ST, Reynolds CP, Kang MH, Maris JM, Billups C, Smith MA, Houghton PJ, Lock RB. Initial testing (stage 1) of the Akt inhibitor GSK690693 by the pediatric preclinical testing program. Pediatr Blood Cancer. 2010; 55: 1329-37. doi: 10.1002/pbc.22710.

105. Kang MH, Reynolds CP, Maris JM, Gorlick R, Kolb EA, Lock R, Carol H, Keir ST, Wu J, Lyalin D, Kurmasheva RT, Houghton PJ, Smith MA. Initial testing (stage 1) of the investigational mTOR kinase inhibitor MLN0128 by the pediatric preclinical testing program. Pediatr Blood Cancer. 2014; 61: 1486-9. doi: 10.1002/pbc.24989.

106. Reynolds CP, Kang MH, Carol H, Lock R, Gorlick R, Kolb EA, Kurmasheva RT, Keir ST, Maris JM, Billups CA, Houghton PJ, Smith MA. Initial testing (stage 1) of the phosphatidylinositol 3' kinase inhibitor, SAR245408 (XL147) by the pediatric preclinical testing program. Pediatr Blood Cancer. 2013; 60: 791-8. doi: 10.1002/ pbc. 24301 .

107. Klempner SJ, Myers AP, Cantley LC. What a tangled web we weave: emerging resistance mechanisms to inhibition of the phosphoinositide 3-kinase pathway. Cancer Discov. 2013; 3: 1345-54. doi: 10.1158/2159-8290.CD-13-0063.

108. Jones DT, Kocialkowski S, Liu L, Pearson DM, Backlund LM, Ichimura K, Collins VP. Tandem duplication producing a novel oncogenic BRAF fusion gene defines the majority of pilocytic astrocytomas. Cancer Res. 2008; 68: 8673-7. doi: 10.1158/0008-5472.CAN-08-2097.

109. Pfister S, Janzarik WG, Remke M, Ernst A, Werft W, Becker N, Toedt G, Wittmann A, Kratz C, Olbrich H, Ahmadi R, Thieme B, Joos S, et al. BRAF gene duplication constitutes a mechanism of MAPK pathway activation in low-grade astrocytomas. J Clin Invest. 2008; 118: 1739-49. doi: $10.1172 / \mathrm{JCI} 33656$. 